\title{
Personel Güçlendirmenin Kurumsal Bağlılığa Etkisi: Güvenlikten Sorumlu Bir Kamu Kurumunda Araştırma*
}

\author{
Hakan GÜRSOY, İshak AYDEMIR ${ }^{* *}$
}

Personel Güçlendirmenin Kurumsal Bağ|lığa Etkisi: Güvenlikten Sorumlu Bir Kamu Kurumunda Araştırma

\section{Özet}

$\mathrm{Bu}$ araştırmanın amacı; kamu kurumlarında personeli güçlendirme faaliyetlerinin kurumsal bağlıık üzerindeki etkilerini değerlendirmektir. Araştırma, bir kamu kurumu olan Jandarma Genel Komutanlığı́nın Ankara'da bulunan komutanlık karargâhında görevli Subay, Astsubay, Uzman Jandarma ve Sivil Memurlarından oluşan 560 personeli üzerinde gerçekleştirilmiştir. Araştırma amacı doğrultusunda veri toplama aracı olarak, 1967 ylında Weiss, Dawis, England ve Lofquist tarafından geliştirilen "Minnesota iş tatmini ölçeği" ve Allen ve Meyer tarafından 1991 ylında geliştirilen "örgütsel bağ|lık ölçeği" kullanılmıştır. Kamu kurumlarında yüksek kalite ve verim elde edilmesinin kurumuna aidiyet duygusu ile bağlanmış personel ile sağlanabileceği, hızla değişen teknolojik çağda faaliyetlerini günün şartlarına göre yerine getirebilmeleri için personel güçlendirme faaliyetlerine önem vermeleri gerektiği, uygulanacak iyi bir personel güçlendirme stratejisi ile kurumun verimlilik düzeyinde yüksek oranda artış olacağı bulgularına ulaşıımışır.

Anahtar Kelimeler: Personel Güçlendirme, Kurumsal Bağlllık, Örgütsel Bağlılık.
The Effect of Employee Empowerment over Institutional Commitment:The Study in a Public Corporation That Responsible to Security

\section{Abstract}

The aim of this study is to evaluate the effects of personal empowerment of employees on institutional commitment in the public service. The study is conducted on 560 officers consisting of Army Officer, Sergeant, Specialist Gendarme and Civil Officers working in Military Police Commandership's headquarter in Ankara. The "Minnesota job satisfaction scale" developed by Weiss, Dawis, England and Lofquist in 1967 and the "organizational commitment scale" developed by Allen and Meyer in 1991 are used. The results indicate that high level of attachment to an organization is a critical factor in achieving high quality and efficiency. it is acknowledged that to keep up with vastly developing technology and conditions of the day, public entities should give importance to empower their employees. A well executed strategy for empowerment of employees increases the efficiency level of the entire entity.

Key Words: Employee Empowerment, Institutional Commitment, Organizational Commitment.

\section{Giriş}

Globalleşen dünyada teknoloji çağının getirdiği hızlı değişim sonucunda kurumlar için; çağa ayak uydurabilmek ve varlığını devam ettirebilmek amacıyla rekabetin, kaliteli ve zamanında hiz-

\footnotetext{
"Yazar Hakan GÜRSOY'un 2014 yılında kabul edilen "Bir modern işletme yönetimi tekniği olarak personel güçlendirmenin kurumsal bağlılığa etkisi : Jandarma Genel Komutanlığı Örneği” konulu Yüksek Lisans tezinden türetilmiştir.

**Hakan GÜRSOY, Doktora Öğrencisi., İstanbul Gelişim Üniversitesi, İşletme Bölümü, hakangursoy44@hotmail.com; İshak AYDEMIR, Doç.Dr., İstanbul Bahçeşehir Üniversitesi, Sağlık Yönetimi Bölümü, ishak72@gmail.com
} 
Hakan GÜRSOY | İshak AYDEMIR

metin gerekliliği ön plana çıkmıştır. Bu amaçlarına ulaşmak isteyen kurumlar, problemlere çözümler üreten, kararlar alan, inisiyatif kullanan ve sonuçların sorumluluğunu taşıyabilecek çalışanlara gereksinim duymuşlardır. Bu nedenle personeli güçlendirme kurumlar için ihtiyaçtan ziyade bir zorunluluk halini almıştır.

Yöneticilerin güçlü, bürokratik engellerin yoğun olarak hissedildiği, merkeziyetçi ve dikey örgütlenmenin var olduğu kamu kurumları ve özellikle Jandarma gibi bir taraftan güvenlik merkezli topluma kapalı diğer taraftan kolluk kuvveti olması nedeniyle toplumla içiçe kurumlar düşünüldügünde, personel güçlendirme çalışmalarının bu kurumlarda uygulanabilirliğinin diğer kurumlara oranla ne kadar zor olacağı anlaşılacaktır. Ancak her ne kadar yukarıda sayılan etmenler olsa da, günümüz şartlarında personel güçlendirmenin kamu yönetiminde uygulamaya başlanmasıyla katılımcı yönetim anlayışının yaygınlaşacağı, katılımcı yönetimle birlikte çalışanların karar verme yetkisi ve sorumluluk alanlarının artacağı, dolayısıyla güçlendirme sürecinin başlayacağı ve bununla birlikte çalışanların kuruma bağ|ııklarında artış olmasının kaçınılmaz hale geleceği değerlendirilmektedir.

Personel güçlendirme sürecinde, yöneticiler ellerinde bulundurdukları gücü diğer çalışanlarla paylaşacaktır. Hem yöneticiler hem çalışanlar hem de kurumlar bu sürecin sonunda büyük fayda sağlayacaklardır. Yöneticiler bu gücü çalışanlarla paylaşmak suretiyle zamandan tasarruf yapmış olacak ve kurum için kritik öneme haiz stratejik faaliyetlere yöneleceklerdir. Çalışanlar ise kendini işin sahibi olarak görmek suretiyle çok yönlü beceriler kazanacak, işlerini daha hızlı ve daha etkin bir şekilde yapacaklardır. Kurumlar ise bu durumdan kalite ve sayısal açıdan daha yüksek bir üretim düzeyi elde ederek verimliliği artırmak suretiyle daha büyük kazanımlar elde etmiş olacaklardır.

Kurumsal bağlılık ise, amaca yönelik uygulanabilir bir personel güçlendirme sonucunda; çalışanın kendisini içinde bulunduğu kurumun bir parçası olarak hissetmesi, kuruma sadık kalarak kurumun çıkarını gözetmesi, aynı zamanda bireysel amaçlarını da göz ardı etmeden kurumsal amaçlara ulaşma yolunda bütün çaba ve becerilerini arzulu bir biçimde ortaya koyması şeklinde ortaya çıkacaktır. Kısaca çalışanların hakları korunmak suretiyle doğru bir şekilde uygulanan personeli güçlendirme, aynı ölçüde kurumsal bağlıı̆ı artırmış olacaktır.

Bu çalışmada kullanılmak üzere araştırmaya uygun olduğu değerlendirilen Weis vd.nin geliştirdiği, Kök (2006, s. 295) tarafından çalışmasında kullandığı 16 sorudan oluşan “Minnesota iş tatmini ölçeği” ile Allen ve Meyer'in geliştirdiği Gürbüz vd. (2013, s. 791).tarafından çalışmalarında kullandığı 10 sorudan oluşan "örgütsel bağlılık ölçeği” kullanılmıştır.

İlgili soruların yer aldığı anketler 560 personel üzerinde uygulanarak bireylere elden dağıtılarak toplandıktan sonra SPSS 18.0 For Windows istatistik paket programına veri girişleri yapılmıştır. Anketin güvenilirliği ölçülmüş, KMO ve Bartlet testi ile faktör analizleri yapılmış ve yapısal geçerlilik ile güvenilirlik doğrulanmıştır. Analiz bölümünde ise ilişkilerin yönü ve derecesini belirlemek, değişkenleri incelemek üzere Pearson Korelasyon Analizi ve Regresyon analizi yapılmıştır. 
Yapılan araştırma sonucunda, özel sektörde olduğu gibi kamuda da gelişen teknolojiyi kullanacak olan personelden kaliteli bir hizmet elde edebilmenin kurumsal bağlı̆ı̆ın artııılmasından geçtiği, bununda kurumuna güçlü aidiyet hissi duyan bireylerle olabileceği gerçeği ortaya çıkmıştır. Halen tüm sektörlerde hizmet veren kamu kurumlarının uygulayacakları iyi bir personel güçlendirme stratejisi ile bağ|ıı̆ı artırabilecekleri ve kurumun hedeflerini yakalayabilecekleri değerlendirilmektir.

\section{Personel Güçlendirme}

Makalenin bu bölümünde "Personel Güçlendirmenin Tanımı Ve Kavramı”, "Personel Güçlendirmenin Tarihsel Gelişimi”, "Personel Güçlendirmenin Temel Unsurları”, "Personel Güçlendirmenin Önemi" başlıkları altında personel güçlendirme konusu işlenecektir.

\subsection{Personel Güçlendirmenin Tanımı ve Kavramı}

İngilizcede "empowerment" sözcüğünün Türkçe karşılığı olarak ele alınan "personel güçlendirme" kavramının özünde işi fiilen yapan bireyin o işle ilgili tüm kararları verebilmesi ve bunun için eğitilmesi konusuna vurgu yapılmıştır. En basit ifadeyle personel güçlendirme, çalışanların yaratıcılık ve motivasyon güçlerinin kullanılması ile eski, modası geçmiş ve emir tarzındaki yönetim uygulamalarından bir an önce uzaklaşılarak örgüt problemlerinin çözülmesi anlamını taşımaktadır (Çelebi, 2009, s. 8).

Türkiye'nin hukuk sisteminde personel güçlendirme ile ilgili herhangi bir düzenleme bulunmamaktadır. Fakat personel güçlendirmeyle ilişkili "yetki devri", "yetki genişliği", "yerindelik" gibi kavramlara rastlanılmaktadır. Kamu yönetimi açısından değerlendirildiğinde; kamu yönetiminde yapılacak hizmetlerin yasal bir dayanağının bulunmasının zorunluluğu, kamusal alandaki her aktivitenin bir hukuki dayanağı olması gerekliliği, diğer örgüt yönetimlerine göre değişiklik arz ettiğini göstermektedir (Çuhadar, 2005, s. 4).

Katılımcı yönetim anlayışının yaygınlaşması ancak personel güçlendirmenin kamu yönetiminde uygulamaya başlanmasıyla mümkün olabilir. Uygulanan katılımcı yönetimle birlikte çalışanların karar verme yetkisi ve sorumluluk alanları artacak, dolayısıyla güçlendirme süreci başlayacak ve bununla birlikte çalışanların kuruma bağlııklarında da bir artış söz konusu olacaktır. Ancak güçlendirmenin başarıyla uygulanması için çalışanların motivasyonlarını artırmaya yönelik çalışmalar yapılması, etkili bir bilgi ve iletişim sisteminin kurulması, tüm yönetim kademelerindeki yöneticilerin güçlendirmeyi mutlaka benimseyip uygulaması gerekmektedir. İyi bir personel güçlendirme disiplini ile çalışanların kuruma bağlılıklarında artış sağlanmış olacağı değerlendirilmektedir (Akçakaya, 2010, s. 167). 
Hakan GÜRSOY | İshak AYDEMIR

Tablo 1'de personel güçlendirmenin özelliklerine bakıldığında ne olup olmadığı daha iyi anlaşılacaktır.

Tablo 1. Personel Güçlendirmenin Özellikleri

\begin{tabular}{|c|c|}
\hline Nedir? & Ne değildir? \\
\hline $\begin{array}{l}\text { Anlaşılabilir bir vizyon, davranışlara yönelik } \\
\text { rehberlik ve açıkça belirtilmiş sınırlar. }\end{array}$ & $\begin{array}{l}\text { Herkesin özgürce hareket edebileceği, istediğini } \\
\text { yapabileceği ve kendi sınırlarını kendisinin çizebile- } \\
\text { ceği bir ortam. }\end{array}$ \\
\hline $\begin{array}{l}\text { Bütün karar ve davranışlara ekip üyelerinin } \\
\text { tümünün yüksek derecede katııımı ve deste- } \\
\text { ğinin alınmasıyla yaratılan uzlaşma. }\end{array}$ & $\begin{array}{l}\text { Her karar ve davranış için bireylerin oy verdiği de- } \\
\text { mokratik bir işleyiş. }\end{array}$ \\
\hline $\begin{array}{l}\text { Performans ve sonuçlara önem verilen bir } \\
\text { ortam. }\end{array}$ & $\begin{array}{l}\text { Sonuçların önemsenmediği, ekibin iyiliği için per- } \\
\text { formans sorunlarının arka plana atıldığı bir ortam. }\end{array}$ \\
\hline $\begin{array}{l}\text { İşi daha etkili bir biçimde yapabilmek için } \\
\text { gerekli olan eğitim, para, zaman konusunda } \\
\text { belirginlik. Ekip olarak hareket etmek, yaratıcı } \\
\text { olmak, sorunları çözmek. }\end{array}$ & $\begin{array}{l}\text { Gerekli araç, yönlendirme ve rehberlik olmadan } \\
\text { işlerin yapılması için ekibin serbest bırakılması. }\end{array}$ \\
\hline $\begin{array}{l}\text { Ekibin başarısı için, bütün ekip üyelerinin } \\
\text { kararlara katııımı, sonuçlar ne olursa olsun } \\
\text { kendisinin ve ekibin davranışlarını sahiplen- } \\
\text { me. }\end{array}$ & $\begin{array}{l}\text { İşler yolunda gitmediğinde suçlama ya da savunma- } \\
\text { ya geçme, özür dileme, sorumluluk almadan, karar } \\
\text { verme ve harekete geçebilme özgürlüğüne sahip } \\
\text { olma beklentisi. }\end{array}$ \\
\hline
\end{tabular}

Kaynak: (Tuğ, 2010, s. 7).

\subsection{Personel Güçlendirmenin Tarihsel Gelişimi}

ABD'nin personel güçlendirme anlayışının temel gelişim yerinin olduğu ve 1920 'li yılların sonrasında içinde bulunduğu ekonomik, politik ve sosyal değişkenlerin bu kavramın ortaya çıkmasında önemli bir rolünün olduğu görülmektedir. Hızla artan küresel rekabet, 1970'lerden sonra önemli konumda bulunan ABD ekonomisini olumsuz etkilemiş, hızlı hareket eden, düzensiz ve hızlı değişen bir çevre oluşmuştur. Geleneksel yönetim yaklaşımlarını eleştiren örgüt kuramcıları alternatif arayışlara girmiş ve müşteri odaklı yönetim biçimlerine önem vermeye başlamışlardır (Atalay, 2009, s. 27).

Personel güçlendirme kavramı 1986 yılında Block tarafından kaleme alınan “The Empowered Manager" adlı kitap ile literatüre girmiş, 1988 yılında Conger ve Kanungo'nun yapmış oldukları çalışmalar ile daha da belirginleşmiştir. Conger ve Kanungo personel güçlendirmenin kurumlara ve insan kaynaklarına etkilerini incelemiş, çalışmalarında güçlendirmeyi “üstün astı ile gücünü paylaş- 
tığı bir süreç" olarak nitelemişlerdir. Tablo 2' de personel güçlendirmenin gelişim seyri yer almakta$\operatorname{dır}(1988$, s. 472).

Tablo 2. Personel Güçlendirmenin Gelişim Seyri

\begin{tabular}{|c|c|c|}
\hline $\begin{array}{l}1920^{\prime} l i \\
\text { ylllar }\end{array}$ & İ̧̧örenin Uyum Göstermesi & Taylorist yaklaşım. \\
\hline $\begin{array}{l}19300^{\prime} l i \\
\text { ylllar }\end{array}$ & $\begin{array}{l}\text { İnsan İlişkileri Yaklaşımı ve } \\
\text { Elton Mayo }\end{array}$ & $\begin{array}{l}\text { İşgörenin motive olabilmesi ve işini en iyi yapabilmes } \\
\text { için "yakın nezaret"e gerek olmadığı anlayışının ortaya } \\
\text { çıkması. }\end{array}$ \\
\hline $\begin{array}{l}1960^{\prime} l i \\
\text { yıllar }\end{array}$ & İş Zenginleştirme & $\begin{array}{l}\text { Belirli düzeyde kontrol ve performans geri beslemes } \\
\text { ile işgörenlere "anlamı"ı işler sunma. }\end{array}$ \\
\hline $\begin{array}{l}19700^{\prime} l i \\
\text { yillar }\end{array}$ & Endüstriyel Demokrasi & $\begin{array}{l}\text { İşçilerin katılım haklarını temel alan bir yaklaşım ve } \\
\text { müşterek anlaşma. }\end{array}$ \\
\hline $\begin{array}{l}1980^{\prime} l i \\
\text { ylllar }\end{array}$ & İşgörenlerin Katılımı & $\begin{array}{l}\text { Bu evrede yeni bir katılım biçimi olarak, müşterek } \\
\text { anlaşmadan çok işgörenlerin katıım biçimleri üzerinde } \\
\text { durulur. }\end{array}$ \\
\hline $\begin{array}{l}\text { 1980'lerin } \\
\text { sonu }\end{array}$ & Personel Güçlendirme & Çağdaş anlamda personel güçlendirme. \\
\hline
\end{tabular}

Kaynak : (Ala, 2010, s. 33)

\subsection{Personel Güçlendirmenin Temel Unsurları}

Yapılan araştırma sonucunda temel unsurlardan bahsederken "işgörenleri güçlendirmenin hayati olması ve ölçülebilmesi için, kurumların stratejik hedefleri ile bireysel hedefler bağlantılı olmalıdır ve güçlendirme stratejik hedeflerle bağdaştığında, alt kademe de bunu uygulamaya geçirmelidir" söylemi ön plana çıkmıştır (Çavuş ve Akgemci, 2008, s. 231).

Literatürde, personel güçlendirme olgusunun başarılı olabilmesi için kurum kültürü içerisine yerleşebilmesi ve takımların güçlendirilmesi sürecinde çeşitli temel unsurların varlığından söz edilmektedir. Bu unsurların ortak özellikleri ise, birbirlerini tamamlayan ve güçlendirme kültürü ile sürecini geliştiren nitelikte olmalarından kaynaklanmaktadır (Aktaş, 2010, s. 65).

Personel güçlendirmede temel unsurlar aşağıdaki gibi sıralanabilir;

- "Katılım ve Karar Verme Yetkisi" unsuru: Çalışanlara yetki vermektedir. 


\section{Hakan GÜRSOY | İshak AYDEMIR}

- "Yenilik" unsuru: İşletme içerisinde yenilikçi (innovation) bir ortamın yaratılmasına doğal olarak destek vermektedir.

- Bilgiye Ulaşabilirlik ve Bilgilerin Paylaşıması" unsuru: Güçlendirmeye hayat vermekte, onun yaşaması için gerekli olmaktadır.

- “Çalışanlar Arasındaki Güven” unsuru: Personel güçlendirmenin, yöneticiler ile çalışanlar arasındaki karşılıklı güven duygusu üzerine inşa edilmesi gerektiğini ortaya koymaktadır.

- “Çalışanları Toplum Önünde Övme” unsuru: Personel güçlendirmeyi hızlandırıcı ve uygulamayı kolaylaştırıcı bir etki yapmaktadır.

- “Ortak Hedeflere Yöneltme” unsuru: Çalışanların, örgütün hedeflerini çok iyi bilmeleri ve örgütü başarıya götürecek çalışmalar yapabilmelerini sağlamaktadır.

- "Sorumluluk" unsuru: Çalışanların, yaptığı işin kendisine ait olduğunu hissetmesi sonucunda, yaptığı işlerin sonuçlarının da kendisine ait olduğunu bilerek daha fazla sorumluluk almasını sağlamaktadır.

- "Yetenekleri Geliştirme ve Yeterlilik" unsuru: Çalışanların, kendi işini yapmada sahip olduğu beceri düzeyini anlatmaktadır.

- "Personelin Eğitimi” unsuru: Çalışanların yeteneklerinin artııılması ve onların kendilerine güven duymaları ile yüksek standartlara ulaşmalarını sağlamaktadır.

- Açık Illetişim Ortamının Sağlanması” unsuru: Çalışanlarının kurum hedef, amaç, plan ve yönetimleri ile bu konularda meydana gelen değişikliklerin çalışanlarla zamanında paylaşılmasını sağlamaktadır.

- "Performans Geri Bildirimi” unsuru: Çalışanlarının başarılı oldukları işlerini övme ve başarısız olan işlerini düzeltme fırsatı sağlamaktadır.

- “Çalışma Şartlarında Esneklik” unsuru: İşi önceden belirlendiği şekilde değil, başka yöntemler kullanmak suretiyle ve başkaları ile iletişim kurarak yapabilme yeteneği olarak tanımlayan ve daha çok verim alınmasını sağlamaktadır.

- "Kurumsal Kaynaklara Ulaşabilirlik" unsuru: Çalışanların güçlendirildiği ortamlarda vazgeçilemez bir koşul olmaktadır.

- "Takım Çalışması" unsuru: Üyelerin birbirleriyle pozitif etkileşim içine girmesini, örgüt hedeflerine daha başarılı ve kolay ulaşılmasını sağlayan önemli bir unsurdur (Aktaş, 2010, s. $65)$. 


\subsection{Personel Güçlendirmenin Önemi}

Kurum personelinin eğitim ve kültür düzeyindeki artış, tüm yetkilerin yöneticide toplandığı merkezi yönetimlerde bazı hoşnutsuzluklara yol açabilmektedir. Merkezi yönetim yapısı yapılacak her şeyin tam ve kesin olarak belli olduğu tekrarlanan görevler için belki uygun olabilmektedir. Fakat böyle bir durum söz konusu olmadığı zaman merkezi yönetim tarzı, bilgi ekonomisinin önemli bir etkeni olan fikirlerin geliştirilmesi ve akışında soruna yol açacaktır. Yani personel güçlendirmeye olan gereksinimin sadece rekabetten kaynaklanmadığı, çalışanların beklentilerinin de belirleyici rol oynadığı görülecektir (Valaderes, 2004, s. 221).

Günümüzde kurum personelinin birçoğu, pasif ve bağımlı birer çalışan olmak yerine, sürekli kendini geliştiren, yetki ve sorumluluk üstlenen, kararlara katılan, aktif bireyler olmayı istemektedirler. Bu istek ve beklenti, personel güçlendirme yaklaşımına olan ilgiyi artıracak, yöneticiler tarafından personelin güçlendirme beklentileri karşılandığı takdirde hem personel ve hem de örgüt için ciddi yararlar sağlanacaktır (Akın, 2010, s. 223).

Conger ve Kanungo'ya göre personeli güçlendirme, üst yönetim tarafından gerçekleştirilen yönetsel faaliyetlerin çalışanlarca nasıl algılandığının tespiti, kurumun zayıf taraflarının tespitiyle bu zafiyetlerin ortadan kaldırılması, yararlı tüm bilgilerin temini ile kurum üyelerinin öz yeterlilik duygularını arttırma sürecidir (1998, s. 474).

Küreselleşen dünyada çevre koşullarının hızla değişimi ve buna paralel olarak gün geçtikçe değişen ve zorlaşan rekabet koşulları, örgütlerde müşteri memnuniyetinin ön plana çıkmasına sebep olmuştur. Bu ise ancak müşteri isteklerine süratle cevap verebilme kapasitesi olan örgütlerce gerçekleştirilebilmektedir. Aynı zamanda yükselen personel kalitesi ve beklentileri, demokratik anlayışın bütün kurum ve kuruluşlarda öneminin artması, personel güçlendirme kavramını kurumların amaçlarına ulaşabilmesi açısından oldukça önemli kılmaktadır (Seçgin, 2007, s. 11).

Çalışanın öz-yeterlilik hissini geliştirebilecek her türlü yönetim biçimi personel güçlendirmeye katkı sağlayacaktır. Çalışanlar, işleri üzerinde kontrol ve sahiplenme hissettiklerinde güçlendirme gerçekleşecek, işi yapan ile karar vereni yakınlaştırarak, işlerin yapılma süresini kısaltacaktır. Güçlendirilmiş çalışanlar, yaptıkları işlerin ve sonuçlarının da kendilerine ait olduğunu görecek ve daha çok sorumluluk üstleneceklerdir. Bu durumda işlerin yapılmasında inisiyatif alacaklar, işlerinden hoşlanacaklar ve kurum içindeki etkinlikleri artacaktır (Çuhadar, 2005, s. 3).

Özetle örgütlü yapıların, dış çevrelerinde meydana gelen değişikliklere daha hızlı bir şekil ve zamanda ayak uydurabilmesi ve çalışanların iş tatminini artırmasının yanı sıra, örgütün verimliliğini de artıran bir uygulama olması nedeniyle personel güçlendirme uygulamaları kurum ve kuruluşlar açısından önemli bir yönetim felsefesi haline gelmiş bulunmaktadır (Seçgin, 2007, ss. 11-12). 
Hakan GÜRSOY | İshak AYDEMIR

\section{Kurumsal Bağlılık}

Makalenin bu bölümünde "Kurumsal Bağ|lığın Tanımı ve Kavramı", "Kurumsal Bağ|lığın Önemi”, "Kurumsal Bağlılı̆ı Etkileyen Faktörler”, "Kurumsal Bağlılık ile Personel Güçlendirme ilişkisi", "Kurumsal Bağ|ı̆ı̆ın Oluşmasında Personel Güçlendirmenin Önemi” başlıkları altında kurumsal bağ|lık konusu işlenecektir.

\subsection{Kurumsal Bağ|ı̆ığın Tanımı ve Kavramı}

Kurumsal bağlılık kavramına ilişkin bugüne kadar birçok araştırma yapılmıştır. Öncelikle Porter, Steers, Mowday ve arkadaşları tarafından tanımlanmaya çalışılan ve bu dönemden itibaren literatüre örgütsel bağ|ılık olarak geçen bu kavram kurumsal bağ|ııkla da eşdeğer anlamda kullanılmaktadır. Bu kapsamda kurumsal bağılık, "çalışanın herhangi bir zorlama olmadan, kendisini içinde bulunduğu kurumun bir parçası biçiminde hissetmesi, kuruma sadık kalarak kurumun çıkarını gözetmesi, aynı zamanda bireysel amaçlarını da göz ardı etmeden kurumsal amaçlara ulaşma yolunda bütün çaba ve becerilerini arzulu bir biçimde ortaya koymaktır" şeklinde tanımlanabilir (Gürül, 2013, s. 27).

Çöl, bağ|lığı, toplum duygusunun olduğu her yerde var olan, toplumsal içgüdünün duygusal "bir kavram ve anlayış biçimi" olarak ele almış, "kölenin efendisine, memurun görevine, askerin yurduna sadâkati anlamındaki bağlıık, eski söyleniş şekliyle sadâkat, sadık olma durumudur" şeklinde ifade edilmiştir. Yine bağlılı̆ı "bir kişiye, bir düşünceye ya da bir kuruma karşı gösterilen ve yerine getirilmek zorunda olunan bir yükümlülük" kavramı olarak değerlendirmiştir (2004, s. 54).

Dağdemir ise kurumsal bağlılığı bir davranış olarak ele almış ve aşağıda yazılı maddelerle ifade etmiştir (2008, s. 23).

- Belli bir kurumun üyesi olmaya ve üyesi olarak kalmaya yönelik güçlü bir arzu.

- Kurum adına yüksek seviyede çaba harcamaya yönelik gönüllülük.

- Kurumun hedef ve değerlerine kesin bir inanç ve bunların kabulü.

Kurumsal bağlılık, sadâkatle aynı anlamı taşıyor gibi görülse de ondan daha güçlü ve daha kapsamlı bir duygudur. Çalışanın, kurumun çıkarlarını kendi çıkarlarından üstün görmesi, kurumun amaç ve değerlerini benimsemesi, kurum için fazladan gayret göstermeye hazır olması ve kurumda kalmaya istekli olması olarak değerlendirilebilir (Erdoğan, 2006, s. 70).

Bu bağlıık çalışanın psikolojik açıdan işyerine bağlanmasını, çalışanın kurumda kalma ve onun için gayret gösterme isteği ile kurumun amaç ve değerlerini benimsemesi olarak ifade edilmektedir. Kurumsal bağlılık bu şekilde değerlendirildiğinde, çalışanların verimliliklerini ve işten ayrılma düşüncelerini etkileyen önemli bir unsur olduğu görülecektir (Doğan ve Kilıç, 2007, s. 39).

Çalışanın, kuruma bağlılık duyabilmesi için; kurumdaki uygulamaların, değerler hiyerarşisinin ve kurum kültürünün, bireyin bakış açısıyla uyumlu olması gerekmektedir. Kurumuna bağlı olan 
birey, kurumla arasındaki ilişki, her ne şekilde gelişirse gelişsin kurumda kalmayı tercih eden, işyerine zamanında ve düzenli gelen, günün tamamını çalışarak geçiren, şirketin varlığını koruyan ve şirketin hedeflerini paylaşan birisi olacaktır (Yenihan, 2010, s. 35).

\subsection{Kurumsal Bağlılığın Önemi}

Modern yönetim kavramları arasında önemli yere sahip olan kurumsal bağ|ılık, çalışanın sadâkati ile o kuruma üyeliğini uzun süre devam ettirme sürecini ifade etmektedir. Kuruma olan sadâkat kültürel değerlerle, kurumsal bağlılık ise iş ve başarıyla yakından ilişkilidir. Yine kuruma olan bağılık ile çalışanın o kuruma olan üyeliğini sürdürme isteği doğru orantılı olmaktadır (Erdoğan, 2006, s. 70).

Kurumların varlığını devam ettirebilmesi, çalışanların kurumdan ayrımamalarıyla ilişkilidir. Kurumlar, varlı̆ı̆ını devam ettirebilmek için çalışanların kurumdan ayrılmasını önlemeye çalışmaktadırlar. Bu, ücret artırma, yükselme olanağı sağlama, özendirici imkânlar sunma gibi olanaklardır. Böylece çalışanların kuruma bağlılı̆ı arttığı ölçüde kurum güçlenmiş olacaktır (Yenihan, 2010, s. 40).

Kurumsal bağııık yalnızca çalışanın kuruma bağ|ı̆ğı olarak tek taraflı ele alınmamalıdır. Çalışan bu özveri ile kurumu daha ileriye götürme gayreti içerisinde bulunuyorken aynı zamanda kurumunda çalışana karşı sorumluluklarını yerine getirmesi gereklidir. Yani kurumsal bağlılık çift taraflı, diğer bir deyişle karşıııklı olmalıdır (Dağdemir, 2008, s. 24).

Kurumların mevcut kaynaklarını verimli bir şekilde kullanamamaları başlıca problemler arasındadır. Bu nedenle kurumlar, çalışanların devir oranından meydana gelen yüksek maliyetleri asgari düzeye indirmek ve devamlılığı sağlamak amacıyla onların kurumlarına olan bağlılıklarını arttırma yollarına giderler. Çünkü kurumuna bağlı çalışanların daha verimli olacakları ve kurumun hedeflerine ulaşması için ellerinden gelen gayreti göstereceklerine inanılır (Mammadova, 2013, s. 53).

Kurumuna karşı bağlılık duyan birey, onun zor zamanlarında da yanında olan, işine düzenli giden, gün boyu çalışan, kurumun varlığını korumaya yönelik gayret sarfeden ve kurum hedeflerini paylaşan çalışan demektir. Bu yönden bakıldığında, kurumsal bağlıı̆ı olan işgücüne sahip olmanın oldukça avantajlı olduğu görülecektir (Tuğ, 2010, s. 51).

Bunun tersi bir durumda yani kurumsal bağ|lığın azalması durumunda, iş yerine gelmeme, iş ile ilgili memnuniyetsizlik, hırsızlık vb. durumlar ortaya çıkabilecek ve kurum bundan zarar görecektir. Ayrıca kurumsal bağlıık, çalışanın devir hızı, motivasyon, iş doyumu ve verimlilik gibi yönetmek açısından da büyük öneme sahiptir (Mammadova, 2013, s. 54).

Sonuç olarak normal şartlarda bile istekleri yeterince karşılanmayan çalışanların beklentiye girmeleri, onların bağ|ılı̆ını azaltıp, stres ve tükenmişliğe yol açabilecektir. Bu nedenle kurumların, faaliyetlerine artan ivmeyle devam edebilmek ve kurum içi huzuru sağlamak için çalışanların örgütsel bağlııklarına yönelik gerekli adımları atması gereklidir. (Gündoğan, 2009, s. 8). 
Hakan GÜRSOY | İshak AYDEMIR

\subsection{Kurumsal Bağ|lığı Etkileyen Faktörler}

Kurumsal bağ|lığı etkileyen faktörler, bireysel ve kurumsal faktörler olmak üzere iki ana başık altında toplanmaktadır. Çalışanın kendisi ve işi ile ilgili taşıdığı özellikler olarak nitelendirilmekte olan bireysel faktörler;

- Yaşı daha küçük olan dolayısıyla daha az tecrübeli olan bireyler ile hizmet süreleri çok olan daha tecrübeli yaşı büyük bireylerin kuruma olan bağlılıkları arasındaki ilişkiyi ortaya çıkaran "Yaş" faktörü,

- Çeşitli nedenlerle kadın ve erkek çalışanlar arasında cinsiyet farkından kaynaklı bağlıık derecelerini ortaya çıkaran "Cinsiyet" faktörü,

- Çalışan bireylerin evli veya bekâr olmaları ile kurumsal bağılık düzeyleri arasındaki ilişkiyi ortaya çıkaran “Medeni durum” faktörü,

- Eğitim düzeyi yüksek olan bireyler ile düşük olan bireylerin ne şekilde kurumsal bağlılığı etkilediğini ortaya çıkaran "Eğitim düzeyi" faktörü,

- Kurumda çalışma süresi az olan bireyler ile gittikçe artan veya çalışma süresi fazla olan bireylerin kurumsal bağlılıkla olan ilişkilerini ortaya çıkaran "Çalışma süresi” faktörü,

- Kurum ile çalışanın uyum içinde olmasına katkı sağlayan, çalışanın beklentilerini belirleyen ve kurumsal bağ|lığa olan etkilerini ortaya çıkaran "iş beklentileri” faktörüdür.

Kurumsal faktörler ise aşağıdaki gibidir;

- Pozitif yaklaşım sergileyen bir yönetici ile çalışanların kuruma olan bağılıklarını ve iş tatminlerini artıracak "Yönetim ve liderlik şekli” faktörü,

- Işin zorunlu kıldığı eğitim düzeyi, teknik ve kişisel gelişime intiyaç olup olmadığı, karmaşıklık derecesi gibi işin niteliğine ait değişkenlerin kurumsal bağlılık ile ilişkisini ortaya çıkaran "İ̧̧in önemi ve özellikleri” faktörü,

- Çalışanların öncelikli amacı olan yaşamlarını devam ettirme ve ihtiyaçlarını karşılamak amacıyla kazanç elde etme için önemli bir isteklendirme aracı olan "Çalışma ücreti” faktörü,

- $\quad$ Örgütü kendisine özgü değer ve kişiliği ile ortaya koyan ve örgütü diğer örgütlerden farklılaştıran ve ayıran varsayımlar, değerler ve sembollerden oluşan "Kurumsal kültür" faktörü,

- Çalışanların ödeme, yükselme ve benzeri sonuçlarla ilgili algılarını belirleyen, "Kurumsal adalet" faktörü, 
- CÇalışanların kendilerine değer verildiğini hissetmelerini sağlayacak "Ödüllendirme” faktörü,

- Kurum içerisinde sinerji oluşturarak, çalışanın kurumunu ve çalışma arkadaşlarını daha çok sevmesini sağlayacak “Takım çalışması” faktörüdür. (Gürsoy, 2014, ss. 55-67)

\subsection{Kurumsal Bağılık ile Personel Güçlendirme ilişkisi}

Birçok akademisyen personel güçlendirme ve kurumsal bağlıık arasındaki ilişkiyi incelemişlerdir. Bunlardan Steers, çalışanların personel güçlendirmeye ilişkin tecrübelerinin kurumsal bağlılık üzerinde etkili olduğunu, çalışanlara karşı gösterilen pozitif davranışların kurumsal bağ|lığı etkileyen önemli etkenlerden olduğunu söylemiştir. Kirkman ve Rosen, kurumsal ve işle ilgili özellikleri, takımların güçlendirilmesi için girdi olarak kullandıkları araştırmalarında, verimlilik, proaktiflik, servis kalitesi, iş tatmini, kurumsal bağ|ıık ve takım bağlıı̆̆ gibi verileri elde etmişlerdir. Cunningham ve Hayman araştırmalarında, yüksek seviyede kurumsal bağılığın ancak personel güçlendirme girişimleriyle ve yönetsel destek ile ortaya çıktığını, Niehoff ve arkadaşları ise hizmet sektörü üzerinde yaptıkları incelemede, psikolojik güçlendirme algısı ile sadâkat arasında pozitif bir ilişkinin varlığını ortaya çıkarmışlardır (Çelebi, 2009, ss. 171-172).

Erstad, personel güçlendirmenin başlamasından sonra, "işgörenleri, tedarikçileri, tüketicileri ve hissedarları ardı ardına değişime sokan zincirleme tepkime başlar" ve ayrıca "güçlendirmeyi uygulamaya koymanın bir yolu, kendi kendini yöneten projeler veya ürün çalışma grupları yaratmaktır" demektedir (1997, s. 329).

Argyris'in 1998 yılında yaptığı “Empowerment: The Emperor's New Clothes” konulu araştırma bu konuda yapılan en temel çalışmalardan biridir. Personel güçlendirme ve kurumsal bağ|ıık ilişkisini psikolojik bir temelde değerlendirip çalışanların kuruma dışsal ve içsel olmak üzere iki tür bağlıığı olduğundan söz etmiştir. Dışsal bağlılık, kurumun, çalışanlarının kendi kaderleri üzerinde çok az kontrole sahip olduğunu kabul etmesi, içsel bağlıık ise çalışanların görev yaptıkları kurum ile ilgili bütün çalışmalara katılmayı gönüllü olarak kabul etmesi anlamına gelmektedir (Doğan ve Kılıç, 2007, s. 47).

Günümüzde personel güçlendirme düzeyi, kurum kültürünün güçlülüğü ile doğrudan bağlantıIı olup kurum kültüründeki değişikliklerin en önemli bir öğesi durumuna gelmiştir (Doğan, 2006, s. 90).

\subsection{Kurumsal Bağ|lığın Oluşmasında Personel Güçlendirmenin Önemi}

Çağa ayak uydurmak isteyen kurumların, faaliyetlerini etkili olarak sürdürebilmesi ancak güçlendirilmiş ve kendilerini kurumuna adamış çalışanların varlığı ile gerçekleşebilecektir. Kurumlar arasında yaşanan yoğun rekabet ve kurumsal değişim, kendilerini iş süreçleri, ürünler, vatandaşa hızlı, güvenli ve en iyi bir şekilde hizmet götürülmesi konularında, gönüllülük ve bağlılık esasına göre, gözle görülür bir şekilde gayret sarf eden bireylerin varlığını gerektirmektedir (Doğan ve Kılıç, 2007, s. 46). 
Hakan GÜRSOY | İshak AYDEMIR

Personel güçlendirme ile çalışanlar, kendi çalışma ortamları ve çalışma biçimlerine ilişkin düzenlemeler yapabilme hususunda kendilerini güçlü hissedecekler, böylece çalışanların kuruma duydukları bağ|ılıkları da artmış olacaktır. Kurumsal bağlılık, çalışanın kurumun menfaatine olacak şekilde davranışlar göstermesi, kurumun hedef ve değerlerini güçlü bir inançla kabullenmesi, kendisini kurum ile özdeşleştirmesi ve kurumsal süreçlere katılımı olarak da tanımlanabilmektedir (Çelebi, 2009, s. 170).

Personel güçlendirmenin önemle uygulandığı kurumlarda çalışanlar, karşııklı ahenk içerisinde hareket ederek, problemleri beraber çözümleyebileceklerdir. Takım çalışması sonucunda, hata yapmaktan korkmayarak beyin fırtınası yapacak ve sorunları çözmenin yeni yollarını bulacaklardır (Mujka, 2011, s. 76).

\section{Yöntem}

Araştırmanın yöntemleri bu bölümde, "Araştırmanın Amacı”, “Araştırmanın Kapsamı”, “Araştırmada Kullanılan Veri Toplama Aracı, Ölçekler ve Kullanılan İstatistik Yöntemler" başlıkları altında incelenecektir.

\subsection{Araştırmanın Amacı}

$\mathrm{Bu}$ araştırmanın amacl; kamu kurumlarında personeli güçlendirme faaliyetlerinin kurumsal bağ|ılık üzerindeki etkilerini değerlendirmektir.

Kamu kurumlarında çalışanların büyük bir çoğunluğu özel şirketlere nazaran gelecek kaygısı fazla bulunmayan memur ve işçiden oluşmaktadır. Kamu kurumlarında çalışan personelden yüksek kalite ve verim elde edilebilmesi, ancak moral ve motivasyonu yüksek, sosyal aktiviteleri ile özlük hakları konusunda problem yaşamayan, gerektiği ölçüde yetkileri artırılmış, takım ruhuna inanmış, kurumuna aidiyet duygusu ile bağlanmış ve kurumsal bağlılığın oluşturulacağı personel ile gerçekleştirilebilir.

Dijital çağ ile birlikte artık birçok işlemin tek tuşla yönetildiği internet çağında, özel işletmeler ve örgütler varlıklarını devam ettirebilmek için gerekli tedbirleri almaktadırlar. Küreselleşen dünyada, sürekli yenilenen teknolojik gelişmelerin hızına ayak uydurmak oldukça zorlaşmış iken, hâlihazırda tüm sektörlerde hizmet vermeye devam eden kamu kurum ve kuruluşlarının buna duyarsız kalmaları imkânsızdır. Bu nedenle tepe yöneticileri, otokratik yönetim, hiyerarşik düzen, bürokratik çıkmazlar gibi birçok engellerle karşı karşıya kalan kamu kurumlarının, işlevselliklerini devam ettirebilmeleri için personel güçlendirme faaliyetlerine daha fazla önem vermeleri gerekliliği ortaya çıkmıştır.

Araştırmaya konu olan, personel güçlendirmenin kurumsal bağlıık üzerine etkileri konusunda kamu kurumlarında çok fazla bir çalışmanın ve araştırmanın yapılamadığı, kıt kaynakların kullanıldığı hususları düşünülürse, bu çalışmanın topluma genellikle kapalı olan kamu kurumlarındaki çalı- 
şanlar üzerinde yapılacak olunması, çalışma sonucunda ortaya konacak verilere daha bir önem ve anlam kazandırmaktadır.

Bu çalışmada Allen ve Meyer'in kullandığı duygusal, devamlı ve normatif bağ|lık olmak üzere üç temel boyut ele alınmak istenmiş ancak üzerinde anket yapılan kamu kurumunun güvenlik merkezli bir kurum olması, yine bu kurumda zorunlu hizmet bulunduğundan ve işten 15 yıl ayrılmak söz konusu olmadığından kurumsal bağ|lığın sadece duygusal bağ|ıık yönü ele alınmış olup diğer iki bağlılık türü değerlendirmeye tabi tutulmamıştır.

\subsection{Araştırmanın Kapsamı}

Araştırma, bir kamu kurumu olan Jandarma Genel Komutanlı̆ı'nın Ankara'da bulunan komutanlık karargâhında görevli Subay, Astsubay, Uzman Jandarma ve Sivil Memurlarından oluşan personeli üzerinde gerçekleştirilmiştir.

\subsection{Araştırmada Kullanılan Veri Toplama Aracı, Ölçekler ve Kullanılan İstatistik Yöntemler}

Araştırma amacı doğrultusunda veri toplama aracı olarak "Minnesota iş tatmini ölçeği" ve "örgütsel bağlıık ile ilgili ölçek" kullanılmıştır. Bu ölçeklerde "kesinlikle katılmıyorum" (1), "katılmıyorum" (2), "kararsızım" (3), "katılıyorum" (4) ve "kesinlikle katılıyorum" (5) değerlerine karşılık gelen $5^{\prime}$ li Likert ölçeği tekniği kullanılmıştır.

Araştırmada iki farklı ölçek kullanılmıştır. İlk ölçek olarak akademik çalışmalarda en fazla tercih edilen 1967 yılında Weiss, Dawis, England ve Lofquist tarafından geliştirilen "Minnesota iş tatmini ölçeği" kullanılmıştır. Kök (2006, s. 295), yazmış olduğu makalesinde bu ölçekten bahsederken "iş tatminini ölçmeye yönelik yöntemlerin başında Minnesota iş tatmini ölçeğinin geldiğini, bu ölçeğin "çalışanların hâlihazırdaki işlerinin hangi yönleriyle (sorumluluk derecesi, ilerleme fırsatları, ödeme imkanları vb. gibi) tatmin edildiklerini ortaya" koymakta, yine "bu ölçekte kişiler ne kadar yüksek oranlar ortaya koyarsa, o kadar fazla işleriyle tatmin olduklarını belirtmiş olmaktadırlar" demektedir. Bu ölçek esas alınarak 16 sorudan oluşan personel güçlendirme bölümü hazırlanmıştır.

İkinci ölçek olarak Allen ve Meyer tarafından 1991 yılında geliştirilen "örgütsel bağ|lık ölçeği" kullanılmıştır. Allen ve Meyer'in bu konuda yaptığı çalışmaları ön plana çıkmıştır. Duygusal, devamlı ve normatif bağlıık olmak üzere üç temel boyutta ele alınmıştır. Bu ölçekte değerlerin yüksek çıkması örgüte olan bağlıı̆ı̆n arttığını ortaya koymaktadır. Ayrıca "bireyin örgütsel hedeflere ve değerlere inanması, onları kabul etmesi, örgütün bir parçası olmak için çaba göstermesi ve organizasyonun sürekli bir üyesi olma kararını almalarını sağlayan" bir gösterge mahiyetindedir (Gürbüz vd., 2013, s. 791). Bu ölçek esas alınarak 10 sorudan oluşan kurumsal bağılıık bölümü hazırlanmıştır. Ayrıca anket uygulamasında; olumsuz soru tipleri ankete katılan katılımcıların daha iyi cevap verebilmeleri amacıyla genellikle olumlu olarak sorulmuştur. İlgili kurumdan gerekli "izin yazısı" alınmasının ardından hazırlanan anketler 13 Ocak 2014 ile 20 Mart 2014 tarihleri arasında personele elden dağıtılıp elden toplanarak uygulanmıştır.

İstatistik yöntemler SPSS 18.0 For Windows istatistik paket programı kullanılarak ölçülmüştür. Öncelikle anketin güvenilirliğini ölçmek için Cronbach alfa $(\boldsymbol{\alpha})$ değeri kullanılmış, yine faktör analizi 
yapabilmek için öncelikle KMO ve Bartlet testi yapılmıştır. Daha sonra faktör analizine geçilmiş, sırasıyla Toplam Varyans Değerleri (Total Variance Explained), “Döndürülmüş Matrix Bileşeni (Rotated Component Matrix) vb. faktör durumları incelenmiş, personel güçlendirme ve kurumsal bağlıık frekans değerleri ortaya çıkarıımıştır. Ayrıca duygusal bağılık ile personeli güçlendirme faktörlerinin aralarındaki ilişkilerin yönü ve derecesini belirlemek, değişkenleri incelemek üzere Pearson Korelasyon Analizi ve Regresyon analizi yapılmıştır.

\section{Bulgular}

Bu bölümde demografik özellikler ile kurumsal bağlılk ve personel güçlendirme ile kurumsal bağlılık arasındaki ilişkinin istatistik değerleri incelenmiş, ileri sürülen hipotezler değerlendirilmiş, yapılan testler sonucunda çıkan değerlerin analizi yapılarak tablolar halinde sunulmuştur.

\subsection{Demografik Özellikler, i̇statistik Analizler ve Bulgular}

Bu araştırmaya toplam 560 personelin katıımı sağlanmıştır. Ankete katılan personelin \%88,8'i erkek, \%11,3'ü kadın, \%5,5’i 20-25, \%13,8'i 26-30, \%22,5'i 31-35, \%26,6'sı 36-40, \%22,5'i $41-45$ ve \%9,1'i 46 yaş üzeri aralığında, \%87,1'i evli, \%12,9'u bekârdır. Çalışanların çoçuğunuz varmı sorusuna \%77,3'ü evet, \%22,7'si hayır cevabı vermiştir. Yine \%5'i lise, \%18,6'sı önlisans, \%64,3'ü Lisans, \%11,8'i yüksek lisans mezunu, \%21,3'ü subay, \%44,8'i astsubay, \%14,8'i uzman jandarma ve \%19,1'i sivil memurdur. Personelin çalıştığı süre \%11,6'sı 1-5, \%17,1'i 6-10, \%21,3'ü 11-15, \%22,7'si $16-20, \% 19,1$ 'i $21-25$ ve $\% 8,2$ 'si 26 yıl ve üzeridir.

Tablo 3. Demografik Özelliklere Göre Kurumsal Bağlılığın Analizi

\begin{tabular}{lllllc}
\hline \hline & & & istatistik & Sayı & $\%$ \\
\hline cinsiyet & Erkek & Ortalama & 43,7103 & 497 & 88,8 \\
& Kadın & Ortalama & 38,5873 & 63 & 11,3 \\
Yaş & $20-25$ & Ortalama & 47,0000 & 31 & 5,5 \\
& $26-30$ & Ortalama & 44,0779 & 77 & 13,8 \\
& $31-35$ & Ortalama & 42,5635 & 126 & 22,5 \\
& $36-40$ & Ortalama & 42,6913 & 149 & 26,6 \\
& $41-45$ & Ortalama & 42,6825 & 126 & 22,5 \\
Medeni & $46-$ üzeri & Ortalama & 43,1765 & 51 & 9,1 \\
Durum & Bekar & Ortalama & 42,6667 & 72 & 12,9 \\
Çocuk & Evli & Ortalama & 43,2029 & 488 & 87,1 \\
\hline
\end{tabular}




\begin{tabular}{|c|c|c|c|c|c|}
\hline Durumu & Hayır & Ortalama & 42,5591 & 127 & 22,7 \\
\hline \multirow{6}{*}{$\begin{array}{l}\text { Eğitim } \\
\text { Durumu }\end{array}$} & Doktora & Ortalama & 40,0000 & 1 & 2 \\
\hline & Y.Lisans & Ortalama & 43,0152 & 66 & 11,8 \\
\hline & Lisans & Ortalama & 43,1833 & 360 & 64,3 \\
\hline & Önlisans & Ortalama & 42,8654 & 104 & 18,6 \\
\hline & Lise & Ortalama & 43,8571 & 28 & 5,0 \\
\hline & Orta & Ortalama & 44,0000 & 1 & ,2 \\
\hline \multirow[t]{4}{*}{ Unvan } & Subay & Ortalama & 45,8655 & 119 & 21,3 \\
\hline & Astsubay & Ortalama & 44,2271 & 251 & 44,8 \\
\hline & Uzm.J. & Ortalama & 40,8554 & 83 & 14,8 \\
\hline & Svl.Me. & Ortalama & 39,2991 & 107 & 19,1 \\
\hline \multirow{6}{*}{$\begin{array}{l}\text { Çalışma } \\
\text { Süresi }\end{array}$} & 1-5 YIl & Ortalama & 44,7077 & 65 & 11,6 \\
\hline & 6-10 Yıl & Ortalama & 42,9583 & 96 & 17,1 \\
\hline & 11-15 YII & Ortalama & 42,3193 & 119 & 21,3 \\
\hline & $16-20$ YII & Ortalama & 42,7087 & 127 & 22,7 \\
\hline & 21-25 YIl & Ortalama & 43,0093 & 107 & 19,1 \\
\hline & 26-üzeri & Ortalama & 44,8478 & 46 & 8,2 \\
\hline
\end{tabular}

(1-22 puan= Zayıf $23-33$ puan= Orta $34-55$ puan= İyi)

Araştırmanın “Hipotez 1: Kurum personelinin duygusal bağ|lık düzeyi demografik özelliklerine göre farklılık göstermemektedir" hipotezine ilişkin yapılan test sonucunda istatistik veriler incelendiğinde önemli ölçüde bir fark görülmemektedir. Tüm demografik özelliklerin frekans değerleri esas alınarak tüm değerlerin 34'ün üzerinde yani iyi seviyede olduğu görülmüş olup bu sonuçla Hipotez 1 kabul edilmiştir.

Faktör analizinde çok karşılaşılan küresellik testi uygulanması gerekli bir testtir. Eğer küresellik testi istatistiksel olarak anlamlı bulunursa faktör analizine geçilir. Bu istatistik özünde verilerin faktör analitik modeli ile modellenip modellenmeyeceğine ilişkin bir ölçüt sunar. Bu ölçütün aralıkları şu şekildedir; 1,00<KMO<0,90=Mükemmel, 0,90<KMO<0,80=iyi, 0,80<KMO<0,70=Orta düzey, $0,70<\mathrm{KMO}<0,60=Z a y ı f, 0,60<\mathrm{KMO}=$ Kötü. 
Hakan GÜRSOY | İshak AYDEMIR

Tablo 4. Personel Güçlendirme KMO ve Bartlet Testi

\begin{tabular}{lll}
\hline \hline \multicolumn{2}{c}{ KMO ve Bartlett Testi } & \\
\hline Kaiser-Meyer-Olkin Örnekleme Yeterlilik Ölçümü & &, 906 \\
Bartlett's küresel Testi & Yaklaşık Ki-Kare & 3561,941 \\
& df (Serbestlik Derecesi) & 91 \\
& Sig. (Önem) &, 000 \\
\hline
\end{tabular}

Yapılan test sonucunda KMO değeri tablo 4'te de görüleceği üzere 0,906 yani mükemmel derecesinde çıkmış olup KMO ve Bartlet testi sonuçları verilerin faktör analizine uygun olduğunu göstermektedir.

Tablo 5. Personel Güçlendirme Varyans Değerleri

\begin{tabular}{|c|c|c|c|c|c|c|c|c|c|}
\hline \multirow{2}{*}{$\begin{array}{l}\text { Bile- } \\
\text { şen }\end{array}$} & \multicolumn{3}{|c|}{ ilk Özdeğer } & \multicolumn{3}{|c|}{ Yüklenmiş Kare Değeri } & \multicolumn{3}{|c|}{ Yüklenmiş Kare Değeri } \\
\hline & $\begin{array}{l}\text { Top- } \\
\text { lam }\end{array}$ & $\begin{array}{l}\text { Var- } \\
\text { yans \% }\end{array}$ & $\begin{array}{l}\text { Birikmiş } \\
\%\end{array}$ & $\begin{array}{l}\text { Top- } \\
\text { lam }\end{array}$ & $\begin{array}{l}\text { Var- } \\
\text { yans \% }\end{array}$ & $\begin{array}{l}\text { Birik- } \\
\text { miş \% }\end{array}$ & $\begin{array}{l}\text { Top- } \\
\text { lam }\end{array}$ & $\begin{array}{l}\text { Var- } \\
\text { yans \% }\end{array}$ & $\begin{array}{l}\text { Birik- } \\
\text { miş \% }\end{array}$ \\
\hline 1 & 5,950 & 42,500 & 42,500 & 5,950 & 42,500 & 42,500 & 3,620 & 25,855 & 25,855 \\
\hline 2 & 1,753 & 12,522 & 55,022 & 1,753 & 12,522 & 55,022 & 3,224 & 23,027 & 48,882 \\
\hline 3 & 1,093 & 7,808 & 62,830 & 1,093 & 7,808 & 62,830 & 1,953 & 13,948 & 62,830 \\
\hline 4 & 783 & 5,590 & 68,421 & & & & & & \\
\hline 5 & 648 & 4,628 & 73,049 & & & & & & \\
\hline 6 & ,625 & 4,466 & 77,514 & & & & & & \\
\hline 7 & ,524 & 3,746 & 81,260 & & & & & & \\
\hline 8 & ,519 & 3,704 & 84,964 & & & & & & \\
\hline 9 & ,480 & 3,427 & 88,391 & & & & & & \\
\hline 10 & ,393 & 2,808 & 91,199 & & & & & & \\
\hline 11 & 379 & 2,707 & 93,906 & & & & & & \\
\hline 12 & ,313 & 2,236 & 96,142 & & & & & & \\
\hline 13 & 274 & 1,955 & 98,096 & & & & & & \\
\hline 14 & ,267 & 1,904 & 100,000 & & & & & & \\
\hline
\end{tabular}


Tablo 5'te görülen Toplam Varyans Değerleri (Total Variance Explained) incelendiğinde özdeğeri 1'in üzerinde olan 3 faktör görülmektedir. Bu 3 faktörün varyansa toplam yaptığı katkı \% 62.830 'dur. "ilk Özdeğer (Initial Eigenvalues)" bölümünün “\% varyans" sütununda faktörlerin ayrı ayrı varyansa yaptıkları katkılara bakıldığında; üçüncü faktörden sonra katkının azaldığı ve bunlar arasındaki farkın birbirine çok yakın olduğu görülmekte ve üç faktör olabileceğini işaret etmektedir.

Tablo 6. Üçlü Faktör Döndürülmüş Matriks Bileşeni

\begin{tabular}{lccc}
\hline \hline & 1 & $\frac{\text { Bileşen }}{2}$ & 3 \\
\hline Per_Güç4 &, 786 &, 167 &, 026 \\
Per_Güç15 &, 771 &, 246 &, 005 \\
Per_Güç2 &, 734 &, 252 &, 138 \\
Per_Güç3 &, 661 &, 368 &, 003 \\
Per_Güç7 &, 643 &, 224 &, 273 \\
Per_Güç6 &, 594 &, 367 &, 230 \\
Per_Güç13 &, 212 &, 808 &, 153 \\
Per_Güç12 &, 292 &, 802 &, 165 \\
Per_Güç14 &, 303 &, 801 &, 086 \\
Per_Güç11 &, 322 &, 688 &, 017 \\
Per_Güç9 &, 566 &, 569 &,- 123 \\
Per_Güç5 &, 075 &, 034 &, 767 \\
Per_Güç1 &, 048 &, 074 &, 763 \\
Per_Güç16 &, 098 &, 103 &, 749 \\
\hline
\end{tabular}

Üçlü faktöre göre alınan yeni çıktı tablolarında, “Döndürülmüş Matrix Bileşeni (Rotated Component Matrix)" tablosu incelenerek, binişiklik gösteren ve eşik yük değerinin (Örneğin: 0.40) altında kalan maddeler belirlenir. Bu değerin altında kalan madde çıkarılarak analize devam edilmelidir. Döndürülmüş Matrix Bileşeni tablo 6'da oluşturulmuştur.

Personel güçlendirme frekans değerleri her soru için spss 18.0 programında tek tek çıkartılarak ölçüm değerleri hesaplanmıştır. Araştırma modeli 1'de personel güçlendirme "çalışma ücreti ve kurumsal adalet", "yönetim ve liderlik, ödüllendirme", "iş beklentisi" olmak üzere 3 bölüm halinde ele alınmıştır. 
Hakan GÜRSOY | İshak AYDEMIR

Tablo 7. Çalışma Ücreti ve Kurumsal Adalet Personel Güçlendirme Değerleri

\begin{tabular}{|c|c|c|c|c|c|c|c|c|c|c|c|c|}
\hline \multicolumn{13}{|c|}{ PERSONEL GÜÇLENDIRME DEĞERLERi } \\
\hline \multirow{2}{*}{ 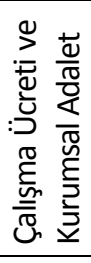 } & \multicolumn{2}{|c|}{$\begin{array}{l}\text { Kesinlikle } \\
\text { Katılmıyo- } \\
\text { rum }\end{array}$} & \multicolumn{2}{|c|}{$\begin{array}{l}\text { Katılmıyo- } \\
\text { rum }\end{array}$} & \multicolumn{2}{|c|}{ Kararsızım } & \multicolumn{2}{|c|}{ Katılıyorum } & \multicolumn{2}{|c|}{$\begin{array}{l}\text { Kesinlikle } \\
\text { Katılıyorum }\end{array}$} & \multirow{2}{*}{ 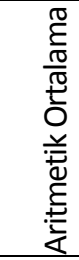 } & \multirow{2}{*}{ 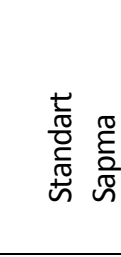 } \\
\hline & Sayı & $\%$ & Sayı & $\%$ & $\begin{array}{l}\text { Sa- } \\
\text { yı }\end{array}$ & $\%$ & Sayı & $\%$ & $\begin{array}{c}\text { Sa- } \\
\text { yı }\end{array}$ & $\%$ & & \\
\hline 2 & 40 & 7,1 & 89 & 15,9 & 102 & 18,2 & 223 & 39,8 & 106 & 18,9 & 3,48 & 1,173 \\
\hline 3 & 34 & 6,1 & 98 & 17,5 & 114 & 20,4 & 219 & 39,1 & 95 & 17,0 & 3,43 & 1,141 \\
\hline 4 & 70 & 12,5 & 95 & 17,0 & 110 & 19,6 & 180 & 32,1 & 105 & 18,8 & 3,28 & 1,291 \\
\hline 6 & 40 & 7,1 & 68 & 12,1 & 134 & 23,9 & 213 & 38,0 & 105 & 18,8 & 3,49 & 1,140 \\
\hline 7 & 29 & 5,2 & 58 & 10,4 & 127 & 22,7 & 220 & 39,3 & 126 & 22,5 & 3,64 & 1,096 \\
\hline 15 & 96 & 17,1 & 112 & 20,0 & 105 & 18,8 & 164 & 29,3 & 83 & 14,8 & 3,05 & 1,331 \\
\hline
\end{tabular}

Araştırmanın "Hipotez 2: "Kurum personelinin çalışma ücreti ve kurumsal adalet ile duygusal bağlııkları arasında pozitif bir ilişki vardır" hipotezine ilişkin yapılan test sonucunda tablo 7’ye bakıldığında genellikle tüm değerlere ait aritmetik ortalamaların iyi seviyede olduğu görülmekte olup bu sonuçla Hipotez 2 kabul edilmiştir.

Çalışanların "çalışma ücreti ve kurumsal adalet" değerlerine ait 15'inci sorudaki “yaptığım işe uygun bir maaş aldığımı düşünüyorum" cevabına katılım ile 4'üncü sorudaki "Türkiye şartları düşünüldüğünde, aldığım maaş geçimimi sağlamaya yeterlidir" cevabına katılımın aritmetik ortalamalarının diğerlerine oranla düşük çıktığı görülecektir. Çıkan ölçüm değerleri çalışma ücretlerinin personelin beklentilerini tam olarak karşılayamadığını, bu konuda iyileştirme faaliyetlerinde bulunmanın gerekliliğini ortaya çıkarmıştır.

Tablo 8. Yönetim ve Liderlik, Ödüllendirme Personel Güçlendirme Değerleri

\begin{tabular}{|c|c|c|c|c|c|c|c|c|c|c|c|c|}
\hline \multicolumn{13}{|c|}{ PERSONEL GÜÇLENDIRME DEĞERLERI } \\
\hline \multirow{2}{*}{ 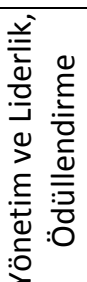 } & \multicolumn{2}{|c|}{$\begin{array}{c}\text { Kesinlikle } \\
\text { Katılmıyor } \\
\text { um }\end{array}$} & \multicolumn{2}{|c|}{$\begin{array}{c}\text { Katılmıyoru } \\
\mathrm{m}\end{array}$} & \multicolumn{2}{|c|}{ Kararsızım } & \multicolumn{2}{|c|}{ Katılıyorum } & \multicolumn{2}{|c|}{$\begin{array}{c}\text { Kesinlikle } \\
\text { Katılıyorum }\end{array}$} & \multirow{2}{*}{ 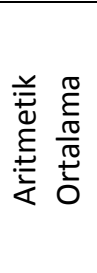 } & \multirow{2}{*}{ 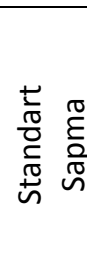 } \\
\hline & $\begin{array}{l}\text { Sa } \\
\text { yı }\end{array}$ & $\%$ & Sayı & $\%$ & Sayı & $\%$ & Sayı & $\%$ & Sayı & $\%$ & & \\
\hline 8 & 41 & 7,3 & 85 & 15,2 & 85 & 15,2 & 229 & 40,9 & 120 & 21,4 & 3,54 & 1,193 \\
\hline 9 & 94 & 16,8 & 143 & 25,5 & 120 & 21,4 & 131 & 23,4 & 72 & 12,9 & 2,90 & 1,292 \\
\hline
\end{tabular}


Eskişehir Osmangazi Üniversitesi Sosyal Bilimler Dergisi

\begin{tabular}{ccccccccccccc}
\hline 11 & 91 & 16,3 & 94 & 16,8 & 120 & 21,4 & 158 & 28,2 & 97 & 17,3 & 3,14 & 1,333 \\
12 & 34 & 6,1 & 83 & 14,8 & 123 & 22,0 & 226 & 40,4 & 94 & 16,8 & 3,47 & 1,117 \\
13 & 26 & 4,6 & 89 & 15,9 & 143 & 25,5 & 206 & 36,8 & 96 & 17,1 & 3,46 & 1,091 \\
14 & 31 & 5,5 & 82 & 14,6 & 113 & 20,2 & 239 & 42,7 & 95 & 17,0 & 3,51 & 1,103 \\
\hline
\end{tabular}

Araştırmanın "Hipotez 3: "Kurum personelinin yönetim ve liderlik, ödüllendirme ile duygusal bağlııkları arasında pozitif bir ilişki vardır" hipotezine ilişkin yapılan test sonucunda tablo 8'e bakıldığında genellikle tüm değerlere ait aritmetik ortalamaların iyi seviyede olduğu görülmekte olup bu sonuçla Hipotez 3 kabul edilmiştir.

Çalışanların "yönetim ve liderlik, ödüllendirme" değerlerine ait 9'uncu sorudaki "kurumumuz çalışanlarının ödüllendirilmesine yönelik teşvik sistemi yeterlidir" cevabına katııı ile 11'inci sorudaki "çalışanlar yaptıkları işe göre değerlendirilir ve ödüllendirilir, çalışan ile çalışmayan bir tutulmaz" cevabına katılımın diğerlerine oranla düşük olduğu, ödüllendirmenin var olduğunu ancak personelin beklentilerini karşlamada yeterli seviyeye ulaşmasını sağlayacak iyileştirme faaliyetlerinde bulunmanın gerekliliğini ortaya çıkarmışıı.

Araştırmanın "Hipotez 4: "Kurum personelinin iş beklentisi ile duygusal bağlıkları arasında pozitif bir ilişki vardır" hipotezine ilişkin yapılan test sonucunda tablo 9'a bakıldığında genellikle tüm değerlere ait aritmetik ortalamaların yüksek seviyede olduğu görülmekte olup bu sonuçla Hipotez 4 kabul edilmiştir.

Tablo 9. İş Beklentisi Personel Güçlendirme Değerleri

\begin{tabular}{|c|c|c|c|c|c|c|c|c|c|c|c|c|}
\hline \multicolumn{13}{|c|}{ PERSONEL GÜÇLENDIRME DEĞERLERI } \\
\hline \multirow{2}{*}{ 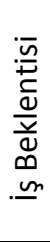 } & \multicolumn{2}{|c|}{$\begin{array}{c}\text { Kesinlikle } \\
\text { Katılmıyorum }\end{array}$} & \multicolumn{2}{|c|}{ Katılmıyorum } & \multicolumn{2}{|c|}{ Kararsızım } & \multicolumn{2}{|c|}{ Katılıyorum } & \multicolumn{2}{|c|}{$\begin{array}{l}\text { Kesinlikle } \\
\text { Katılıyorum }\end{array}$} & \multirow{2}{*}{ 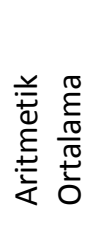 } & $\frac{\pi}{\varepsilon}$ \\
\hline & Sayı & $\%$ & Sayı & $\%$ & Sayı & $\%$ & Sayı & $\%$ & Sayı & $\%$ & & $\begin{array}{l}\frac{1}{\pi} \\
\frac{0}{0} \\
\frac{D}{\pi} \\
\tilde{n}\end{array}$ \\
\hline 1 & 14 & 2,5 & 12 & 2,1 & 30 & 5,4 & 138 & 24,6 & 366 & 65,4 & 4,48 & ,887 \\
\hline 5 & 11 & 2,0 & 15 & 2,7 & 40 & 7,1 & 186 & 33,2 & 308 & 55,0 & 4,37 & 879 \\
\hline 16 & 11 & 2,0 & 11 & 2,0 & 42 & 7,5 & 238 & 42,5 & 258 & 46,1 & 4,29 & ,842 \\
\hline
\end{tabular}

Çalışanların "iş beklentisi" değerlerine ait çıkan ölçüm değerlerinin oldukça yüksek çıkması, personelin kişisel gelişimi ile özlük haklarında iyileştirme yapııması için kurum tarafından yapılacak her türlü faaliyetin personel tarafından arzulandığını ve desteklendiğini göstermektedir. 
Hakan GÜRSOY | İshak AYDEMIR

Tablo 10. Kurumsal (Duygusal) Bağlılık Kişisel Değerleri

\begin{tabular}{|c|c|c|c|c|c|c|c|c|c|c|c|c|}
\hline \multicolumn{13}{|c|}{ "KURUMSAL BAĞLILIK DEĞERLERI } \\
\hline \multirow{3}{*}{$\begin{array}{l}\bar{\delta} \\
\text { s̀ } \\
0 \\
\bar{s} \\
\bar{s} \\
0\end{array}$} & \multirow{2}{*}{\multicolumn{2}{|c|}{$\begin{array}{c}\text { Kesinlikle } \\
\text { Katılmıyor } \\
\text { um }\end{array}$}} & \multirow{2}{*}{\multicolumn{2}{|c|}{$\begin{array}{c}\text { Katılmıyor } \\
\text { um }\end{array}$}} & \multicolumn{2}{|c|}{ Kararsızım } & \multicolumn{2}{|c|}{ Katılıyorum } & \multirow{2}{*}{\multicolumn{2}{|c|}{$\begin{array}{c}\text { Kesinlikle } \\
\text { Katılıyorum }\end{array}$}} & \multirow{3}{*}{ 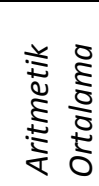 } & \multirow{3}{*}{ 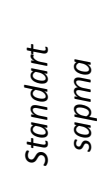 } \\
\hline & & & & & & & & & & & & \\
\hline & Sayı & $\%$ & Sayı & $\%$ & Sayı & $\%$ & Sayı & $\%$ & Sayı & $\%$ & & \\
\hline 1 & 15 & 2,7 & 48 & 8,6 & 50 & 8,9 & 214 & 38,2 & 233 & 41,6 & 4,08 & 1,042 \\
\hline 2 & 18 & 3,2 & 22 & 3,9 & 73 & 13,0 & 212 & 37,9 & 235 & 42,0 & 4,11 & 993 \\
\hline 3 & 14 & 2,5 & 20 & 3,6 & 52 & 9,3 & 207 & 37,0 & 267 & 47,7 & 4,24 & ,940 \\
\hline 4 & 20 & 3,6 & 27 & 4,8 & 88 & 15,7 & 201 & 35,9 & 224 & 40,0 & 4,04 & 1,035 \\
\hline 11 & 11 & 2,0 & 24 & 4,3 & 88 & 15,7 & 221 & 39,5 & 216 & 38,6 & 4,08 & 941, \\
\hline
\end{tabular}

Tablo 11. Kurumsal (Duygusal) Bağlılık Kurumsal Değerleri

\begin{tabular}{|c|c|c|c|c|c|c|c|c|c|c|c|c|}
\hline \multicolumn{13}{|c|}{ "KURUMSAL BAĞLILIK DEĞERLERI } \\
\hline \multirow{2}{*}{ 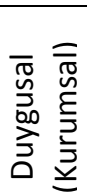 } & \multicolumn{2}{|c|}{$\begin{array}{c}\text { Kesinlikle } \\
\text { Katılmıyor } \\
\text { um }\end{array}$} & \multicolumn{2}{|c|}{$\begin{array}{l}\text { Katılmıyor } \\
\text { um }\end{array}$} & Kararsızım & sızım & \multicolumn{2}{|c|}{ Katılıyorum } & \multicolumn{2}{|c|}{$\begin{array}{c}\text { Kesinlikle } \\
\text { Katılıyorum }\end{array}$} & \multirow{2}{*}{ 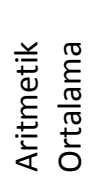 } & \multirow{2}{*}{ 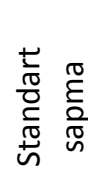 } \\
\hline & Sayı & $\%$ & Sayı & $\%$ & Sayı & $\%$ & Sayı & $\%$ & Sayı & $\%$ & & \\
\hline 5 & 15 & 2,7 & 30 & 5,4 & 68 & 12,1 & 244 & 43,6 & 203 & 36,3 & 4,05 & 969 \\
\hline 6 & 34 & 6,1 & 74 & 13,2 & 150 & 26,8 & 195 & 34,8 & 107 & 19,1 & 3,48 & 1,124 \\
\hline 7 & 12 & 2,1 & 32 & 5,7 & 111 & 19,8 & 247 & 44,1 & 158 & 28,2 & 3,91 & 946 \\
\hline 8 & 26 & 4,6 & 61 & 10,9 & 144 & 25,7 & 217 & 38,8 & 112 & 20,0 & 3,59 & 1,068 \\
\hline 9 & 32 & 5,7 & 77 & 13,8 & 160 & 28,6 & 191 & 34,1 & 100 & 17,9 & 3,45 & 1,106 \\
\hline 10 & 7 & 1,3 & 30 & 5,4 & 65 & 11,6 & 247 & 44,1 & 211 & 37,7 & 4,12 & 899 \\
\hline
\end{tabular}

Araştırmanın "Hipotez 5: "Personel güçlendirme ile duygusal bağlılık arasında pozitif bir ilişki vardır" hipotezine ilişkin yapılan test sonucu tablo 10 ve 11'de görüldüğü gibi kişisel ve kurumsal olarak incelendiğinde genellikle tüm değerlere ait aritmetik ortalamaların iyi seviyede olduğu görülmekte olup bu sonuçla Hipotez 5 kabul edilmiştir.

Kurumsal bağlıık değerleri ölçüldüğünde; personelin kişisel değerler açısından çalıştığı kurumu sahiplenmesi ve kendisini kuruma ait görme duygusunun yüksek seviyede olduğu görülecektir. Ancak kurumsal değerler açısından 6'ncı sorudaki "geçmiş yıllara kıyasla, haksızlığa uğradığımda, yasal haklarımın sonuçlandıılacağı kurum kültürünün oluştuğunu düşünmekteyim" cevabına katıIım, 8'inci sorudaki "kurumumuzda yöneticilerin çalışanlara yönelik tutum ve davranışları genel 
olarak olumludur" cevabına katılım ile 9'uncu sorudaki "kurumumuzun yöneticileri sorunlara çözüm bulmada yapıcı ve demokratik bir yaklaşım sergiler" cevabına katılımın diğerlerine oranla düşük olduğu görülecektir. Kararsızların en çok olduğu katılım burada gerçekleşmekte olup yöneticilerin bu konular da çalışmalara daha fazla ağırlık vermeleri gerektiği değerlendirilmektedir.

\subsection{Korelasyon Analizi}

Duygusal bağ|ılık ile personeli güçlendirme faktörlerinin aralarındaki ilişkilerin yönü ve derecesini belirlemek üzere yapılan Pearson Korelasyon Analizine ilişkin bulgular tablo 12'de yer almaktadir.

Tablo 12. Pearson Korelasyon Analizi

\begin{tabular}{ccccc}
\hline \hline Sayı=560 & duybağ & yönlidöd & çalückurad & işbek \\
duybağ & 1 &, $667^{* *}$ &, $596^{* *}$ &, $402^{* *}$ \\
yönlidöd & 1 &, $704^{* *}$ &, $186^{* *}$ \\
çalückurad & & 1 &, $245^{* *}$ \\
işbek & & & 1 \\
\hline
\end{tabular}

Değişkenler arasındaki ilişkiyi incelemek üzere yapılan korelasyon analizinde, korelasyon katsayısının aldığı değer ve anlam düzeyleri tablo 12 'de yansıtılmıştır. Tabloya bakıldığında, pozitif yönde en yüksek derecede anlamlı ilişkinin "yönetim ve liderlik, ödüllendirme" ve "çalışma ücreti ve kurumsal adalet" değişkenleri arasında $(r=0,704 ; p<0,01)$ olduğu görülmektedir. Yine ortaya çıkan ilişkilerin bazılarına bakıldığında; "duygusal bağılık işlevi ile "yönetim ve liderlik, ödüllendirme" işlevi arasında nispeten güçlü $(0,667) ;$ "duygusal bağlıık" işlevi ve "çalışma ücreti ve kurumsal adalet" işlevi arasında çok az güçlü $(0,596)$; "duygusal bağlıık" "iş beklentisi" işlevi arasında korelasyon katsayısı ile temsil edilen çok az zayıf $(0,402)$ bir ilişkinin olduğu $(p<0,01)$ saptanmıştır.

\subsection{Regresyon Analizi}

Regresyon analizi sonucu elde edilen $R^{2}$ değeri 0,543 değeri ile yüksek bir oranda çıkmıştır. Bu değerin anlamı, duygusal bağ|lıı bağımlı değişkeninde değişimin personel güçlendirmeyi oluşturan 3 bağımsız değişkeni tarafından ne kadar anlamlandırılabildiği bir ölçü değeridir. tablo 13’te görüldüğü üzere bu değer bize duygusal bağ|lığı artıran üç düzeyin, \% 54,3 oranda açıklayabildiğini göstermektedir. 
Hakan GÜRSOY | İshak AYDEMIR

Tablo 13. Regresyon Analizi

\begin{tabular}{|c|c|c|}
\hline \multirow[t]{2}{*}{ Bağımlı Değişkenler } & \multicolumn{2}{|c|}{$\begin{array}{c}\text { Bağımsız Değişken } \\
\text { Duygusal Bağlılık }\end{array}$} \\
\hline & $\beta$ & $\mathrm{t}$ \\
\hline Çalışma Ücreti ve Kurumsal Adalet & 0.189 & 4.629 \\
\hline Yönetim ve Liderlik, Ödüllendirme & 0.485 & 12.007 \\
\hline İş Beklentisi & 0.266 & 8.977 \\
\hline $\mathrm{F}$ & \multicolumn{2}{|c|}{220.251} \\
\hline$R^{2}$ & \multicolumn{2}{|c|}{0.543} \\
\hline dzlt. $R^{2}$ & \multicolumn{2}{|c|}{0.541} \\
\hline \multicolumn{3}{|c|}{ * $\quad(p<0,05)$ düzeyinde anlamlı TEK YÖNLÜ } \\
\hline \multicolumn{3}{|c|}{ ** $(p<0,01)$ düzeyinde anlamlı TEK YÖNLÜ } \\
\hline
\end{tabular}

Katılımcıların duygusal bağ|ıık düzeyini etkileyen "çalışma ücreti ve kurumsal adalet" değişkeni $p<0.05$ anlam düzeyinde 0.189, "yönetim ve liderlik, ödüllendirme" değişkeni $p<0.05$ anlam düzeyinde 0.485 , "iş beklentisi" değişkeni $p<0.05$ anlam düzeyinde 0.266 değeri ile tabloda belirtilmiştir. Bu değerler hipotezlerin kabul edildiğini göstermektedir.

\section{Sonuç ve Öneriler}

Kamu kurumlarında çalışanların büyük bir çoğunluğu memur ve işçiden oluşmakta ve bu çalışanların özel şirketlere nazaran gelecek kaygısı bulunmamaktadır. Kamu kurumlarındaki çoğu çalışanların kadrolu olması nedeniyle işten çıkarma, görevine son verme vb. etkenler özel şirketlerle kıyaslanamayacak kadar azdır. Yani yöneticiler bir nevi mevcut personel ile çalışmak zorundadır. Bu nedenle; kamu kurumlarında yüksek kalite ve verim elde edebilmenin, sonucunda kurumsal bağ|ılığın oluşturulacağı, moral ve motivasyonu yüksek olan, takım ruhuna inanan, sosyal aktiviteleri ile özlük hakları konusunda problem yaşamayan, gerektiği ölçüde yetkileri artırılmış, kurumuna aidiyet duygusu ile bağlanmış personel ile sağlanacağı dikkate alınmalıdır.

Globalleşen dünyada, dijital çağ ile birlikte birçok işlemin tek tuşla yönetildiği internet çağında, özel işletmeler ve örgütler varlıklarını sürdürebilmeleri, daha kaliteli hizmet verebilmeleri amacıyla gereken tedbirleri almaktadırlar. İşte sürekli yenilenen teknolojik gelişmelerin hızına ayak uydurmanın zor olduğu bir dönemde, hâlihazırda tüm sektörlerde hizmet vermeye devam eden kamu kurum ve kuruluşlarının buna duyarsız kalmaları asla düşünülemez. Otokratik yönetim, hiyerarşik düzen, bürokratik çıkmazlar vb. birçok engellerle karşı karşıya kalan kamu kurumlarının, faaliyetlerini çağın gereklerine göre yerine getirebilmeleri için mutlak surette personel güçlendirme faaliyetlerine önem vermeleri gerekmektedir.

Kurumların uygulayacağı iyi bir personel güçlendirme strateji ve aidiyet duygusu ile kurumuna bağlanan personel kendisini güçlü hissedecektir. Kurumsal bağlılığın oluşması sonucunda, personelin, kurumun menfaatine olacak şekilde davranışlar göstermesi, kendisini çalıştığı kurum ile özdeş- 
leştirerek kurumun hedef ve değerlerini kendi hedef ve değerleriyle bir tutması, kurumun verimlilik düzeyinde yüksek oranda artışa yol açacaktır.

Anketlerden elde edilen sonuçlar ışı̆̆ında getirilebilecek öneriler aşağıdaki gibidir;

- Anket çalışmasına katılan birçok personelin soruları cevaplarken kararsız kaldığı görülmüştür. Başta bu çalışanlar olmak üzere tüm personelin kuruma aidiyet duygusunun artırılması için personel güçlendirme çalışmalarına hız verilmelidir.

- Kamu kurumlarının nitelikli personel konusunda özel sektör ile aynı başarıyı yakalayabilmesi ve rekabet edebilmesi için, ücret ve ödüllendirmenin iş verimliliğini artırdı̆̆ı varsayımıyla bu konuda daha fazla çalışmalar yapmalı, çalışanlara başarı belgelerinin yanı sıra nakdi ödüller, prim vb. maddi yönden destek sağlayıcı ödüller vermelidir.

- Yöneticiler, alt kademedeki personeli yetkilendirmeli ve sorumluluk sahibi bireyler olarak yönetim faaliyetlerine katmalıdır.

- Kamu kurumları, kamuya yani vatandaşlara daha iyi hizmet verebilmek için gelişen teknolojik değişimlere ayak uydurabilmeli, bunun içinde gelişmeleri yakından takip ederek, personelini kurs, seminer, bilgilendirme vb. faaliyetler konusunda sürekli yetiştirmelidir.

- Kurum başarısının en üst seviyelere çıkarılması isteniyorsa, çalışanların moral ve motivasyonu ön planda tutulmalı, kurum içerisinde birlik ve beraberliğin oluşturulması için mutlaka takım çalışmasına önem verilmelidir.

- Kurumun vizyon ve misyonları doğrultusunda hedeflerini gerçekleştirmek isteyen kamu kurumlarının yöneticileri, personelini güçlendirmek için mutlaka bir takım çalışmalar yapmalıdır. Problemlerden korkmadan, bu problemlerin çözümünün yine bu personelle birlikte aşılacağı sonucundan kaçmamalıdır.

- Kararlııkla, samimi, eleştiriye açık, şeffaf, özverili ve gerçekçi olmalıdırlar.

Araştırmada kurum personeli üzerinde duygusal bağlılık boyutunda personel güçlendirme ile kurumsal bağlılık arasındaki ilişki araştırımış, kullanılan anket uygulamasının personel güçlendirme ile kurumsal bağılık ölçüm değerleri incelendiğinde; kurum ve yöneticileri tarafından özellikle son yıllarda personel güçlendirme faaliyetleri ile ilgili çalışmalar yapıldığı, bu çalışmaların moral ve motivasyon açısından çok önemli olduğu, takım çalışmasına önem verilmesi gerektiği, ücret ve ödüllendirme konusunda daha fazla çalışmalar yapılmasının kaçınımaz olduğu, iş verimliliği açısından sayıları küçümsenemeyecek kadar çok olan kararsızların somut olarak ikna edilmesinin gerektiği vb. konular ön plana çıkmaktadır.

Ayrıca kurumun personel güçlendirme çalışmaları ne aşamada olursa olsun, çalışanların kuruma ve yöneticilere olan inancının devam ettiği, kurumunu sahiplendiği, işini sevdiği, kurumunun 
Hakan GÜRSOY | İshak AYDEMIR

başarısını kendi başarısı olarak gördüğü de yapılan kurumsal bağılık ölçüm değerlerinde görülmektedir.

\section{Kaynaklar}

Akçakaya, M. (2010). “Örgütlerde Uygulanan Personel Güçlendirme Yöntemleri: Türk Kamu Yönetiminde Personel Güçlendirme”. Karadeniz Araştırmaları, sayı 25, 145-174

Akın, M. (2010). “Personeli Güçlendirme Algılaması, Örgüt İklimi Algılaması Ve Yaratıcı Kişilik Özelliklerinin Örgüt Düzeyinde Yaratıcı Çıktılar Üzerindeki Doğrudan Ve Dolaylı Etkileri”, Sosyal Bilimler Enstitüsü Dergisi, Sayı: 29, 211-238.

Aktaş, Y. (2008). Personeli Güçlendirmenin İnsan Kaynakları Yönetimindeki Yeri: Bir Örnek Olay, Yüksek Lisans Tezi, Sakarya Üniversitesi, Sosyal Bilimler Enstitüsü, Sakarya.

Ala, Ş. (2010). Personeli Güçlendirmenin, Örgütsel Vatandaşlık Davranışı Üzerindeki Etkisinde Etiksel Davranışın Rolü, Yüksek Lisans Tezi, Selçuk Üniversitesi, Sosyal Bilimler Enstitüsü, Konya.

Atalay, G. C. (2009). Personel Güçlendirmeye Dayalı İnsan Kaynakları, Yönetimi İşlevlerinin Örgütsel Vatandaşık Davranışına Etkisi ve Eczacıbaşı Topluluğu'nda Bir Araştırma, Doktora Tezi, Dumlupınar Üniversitesi, Sosyal Bilimler Enstitüsü, Kütahya.

Conger, J. A. and Kanungo, R. N. (1988). "The Empowerment Process: Integrating Theory and Practise", Academy of Management Review, 13 (3). No:3, 471-482.

Çavuş, M. F. ve Akgemci, T. (2008). "İ̧̧letmelerde Personel Güçlendirmenin Örgütsel Yaratıclıı ve Yeniliğe Etkisi: İmalat Sanayinde Bir Araştırma”, Selçuk Üniversitesi, Sosyal Bilimler Enstitüsü Dergisi, 20:2, 229-241.

Çelebi, M. A. (2009). Örgütsel Bağ|ı̆ı̆ın Sağlanılmasında Bir Araç Olarak Personel Güçlendirme, Yüksek Lisans Tezi, Karamanoğlu Mehmet bey Üniversitesi, Sosyal Bilimler Enstitüsü, Karaman.

Çöl, G. (2004). Güçlendirme ve Örgütsel Bağlıık illişkisi Üzerine Bir Araştırma, Doktora Tezi, Gebze Yüksek teknoloji Enstitüsü, Sosyal Bilimler Enstitüsü, Gebze.

Çuhadar, M. T. (2005). "Türk Kamu Yönetiminde Personel Güçlendirme: Sorunlar ve Çözüm önerileri”, Erciyes Üniversitesi İktisadi ve İdari Bilimler Fakültesi Dergisi, Sayı 25, 3-4.

Dağdemir, A. (2008). Kurum Kimliği ve Kurumsal Bağlılık Arasındaki ilişki, Kurum Kimliğinin Çalışanların Kurumsal Bağlııkları Üzerindeki Etkilerinin Bir İşletmede Araştırıması, Doktora Tezi, Anadolu Üniversitesi, Sosyal Bilimler Enstitüsü, Eskişehir.

Doğan, S. (2006). Personel Güçlendirme; Rekabette Başarının Anahtarı, Empowerment. (2.Baskı) İstanbul: Kare Yayınları, ISBN 975-8980-65-3. 
Doğan, S. ve Kılıç, S. (2007). “Örgütsel Bağlılığın Sağlanmasında Personel Güçlendirmenin Yeri ve Önemi”, Erciyes Üniversitesi İktisadi ve İdari Bilimler Fakültesi Dergisi, Sayı: 29, 37-61.

Erdoğan, S. (2006). Yeni Yönetim Anlayışı Açısından Aidiyet Duygusu Ve Hizmet Sektöründe Bir Uygulama, Yüksek Lisans Tezi, Uludağ Üniversitesi, Sosyal Bilimler Enstitüsü, Bursa.

Erstad, M. (1997). "Empowerment and Organizational Change", International Journal Of Contenporay Hospitality Management, Vol:9, No:7, 329.

Gündoğan, T. (2009). Örgütsel Bağlııı: Türkiye Cumhuriyet Merkez Bankası Uygulaması, Uzmanlık Yeterlilik Tezi, Türkiye Cumhuriyet Merkez Bankası, İnsan Kaynakları Genel Müdürlügü, Ankara.

Gürbüz, G., Kumkale, i., Oğuzhan, A. (2013). “Bankacllık Sektöründe Personel Güçlendirme Uygulamalarının Örgütsel Bağlıı̆a Etkisi: Trakya Bölgesi Bankalarında Araştırma”. Uluslararası Avrasya Ekonomileri Kongresi, St.Petersburg, Rusya, 17-18 Eylül 2013.

Gürül, B. (2013). Takım Çalışması İle Örgütsel Bağılıı Arasındaki ilişkiye Yönelik Uygulamalı Bir Araştırma, Yüksek Lisans Tezi, Aydın Üniversitesi, Sosyal Bilimleri Enstitüsü, Aydın.

Kök Bayrak, H. (2006). "Iş Tatmini ve Örgütsel Bağ|lığın İncelenmesine Yönelik Bir Araştırma”, İktisadi ve İdari Bilimler Dergisi, Cilt 20, Sayı 1, 295.

Mammadova, i̇. (2013). İş Tatmini Ile Örgütsel Bağlılık Arasındaki ilişki Ve Bir Uygulama, Yüksek Lisans Tezi, Aydın Üniversitesi, Sosyal Bilimler Enstitüsü, İstanbul.

Mujka, F. (2011). Personel Güçlendirme İle Örgütsel Bağlılık Arasındaki ilişki Ve Bir Araştırma, Yüksek Lisans tezi, İstanbul Üniversitesi, Sosyal Bilimler Enstitüsü, İstanbul.

Seçgin, Y. (2007). Otel İşletmelerinde Personeli Güçlendirme Yönetimi ve Bir Uygulama, Yüksek Lisans Tezi, Gaziosmanpaşa Üniversitesi, Tokat.

Tuğ, Ö. (2010). İşgören Güçlendirmenin Örgütsel Bağlılığa Etkisi Ve Bir Uygulama, Yüksek Lisans Tezi, Dumlupınar Üniversitesi, Sosyal Bilimler Enstitüsü, Kütahya.

Valaderes, K. (2004). “The Practicality of Employee Empowerment: Supporting a Psychologically Safe Culture", Health Care Manager, Vol. 23, No. 3, 221.

Yenihan, B. (2010). Türk Illaç Sektöründe Çalışan Tıbbi Tanıtım Temsilcilerinin İş Doyumu Ve Kurumsal Bağlılık Düzeylerinin İncelenmesi, Yüksek Lisans Tezi, Sakarya Üniversitesi, Sosyal Bilimler Enstitüsü, Sakarya. 